\title{
Interview with Incoming GODORT Chair
}

Susanne Caro

\section{Favorite spot in Fargo / North Dakota}

My favorite spot is Island Park. It is near the river, has music and dancing during the summer, and wonderful, big trees. It is like a little forest in the middle of Fargo.

\section{Favorite pastime/hobby}

I am a cos-player. It mixes some of my passions: science fiction, sewing, and art. I enjoy the challenge of taking something that was a 2-D image and making something that works on a real human. I've also started doing standup comedy.

\section{Favorite TV shows}

Buffy the Vampire Slayer for the great writing and character development; $D r$. Who for the creativity and variety; Game of Thrones because I now I just want to know what happens next and I don't think George R. R. Martin is going to finish writing the series.

\section{Favorite book}

I have a favorite series: Discworld, by Terry Pratchett. They are funny and cover so many topics, from politics to vampires. Reoccurring characters include Death, semi-sentient luggage, witches, wizards, a police detective, and gods. There are over forty books in the series and are a great form of escapism.

\section{Favorite government document}

I still love Dream Anatomy (National Institutes of Health, 2006). It explores the National Library of Medicine's collection of historic anatomy texts. It is a beautiful book. I had one of the images from the book enlarged to a poster for an exhibit, and it is now in my office.

\section{Favorite movies}

Six String Samurai. In a world where the Russians won a war against the US in the 1960s, the only free territory left is Las Vegas where Elvis rules as king. But the king is dead and Buddy Holly is making his way there to claim the throne armed with a guitar and a katana. Russian rockabilly soundtrack by the Red Elvises.

\section{On your reading list now}

- In the Name of Science: A History of Secret Programs, Medical Research, and Human Experimentation by Andrew Goliszek.

- Cold War in a Cold Land: Fighting Communism on the Northern Plains by David Walter Mills.

- The Long Cosmos by Terry Pratchett.

\section{Music on your phone}

Fallout 4 Playlist. It is a mix of 1950 s and 1960s with an atomic theme.

\section{Favorite drink}

Red wine or green tea with jasmine.

\section{Favorite type of food}

The state question of New Mexico comes from the restaurant industry: "Red or green (chile)?" For me, it is green. I lived in Santa Fe, New Mexico, for many years and became addicted to green chile. You can add it to just about anything. Christmas (red and green chile) is a valid answer.

\section{Favorite conference city}

New Orleans, for the food. The conference center is great for getting your steps in but the crawfish étouffée and beautiful restaurants in the French Quarter are the best. I need to explore more of the restaurants there.

\section{Favorite vacation spot}

Camping on the California coast. I love going up Highway 1, the beaches and hiking around Big Sur, walking among the redwoods, and if you are there at the right time of year, picking wild blackberries.

\section{Historical figure you'd like to meet}

This is worse than the favorite book question! Either Mary Edwards Walker, Eleanor of Aquitaine, Eleanor Roosevelt, Dorothea Dix, or Mark Twain.

\section{Pet peeve}

Saying that someone was a person of their time to excuse whatever they did.

\section{What inspires you about your job?}

My colleagues. I've had the honor to work with some wonderful, passionate, quirky, and interesting people. 